\title{
KINEMATICAL ANALYSIS, POLE FORCES AND ENERGY COST OF NORDIC WALKING - SLOPE INFLUENCE
}

\author{
Zdeněk Svoboda, Pavel Stejskal, Aleš Jakubec, Jakub Krejčí
}

Faculty of Physical Culture, Palacký University, Olomouc, Czech Republic

Submitted in April, 2010

BACKGROUND: Several studies concerning Nordic walking (NW) have been reported on however previous investigations have usually focused only on physiological variables or on the kinematics of a moving subject with poles. Until now, only one study that observed the generation of upper limb force acting on a pole has been presented. In our pilot study NW was observed in a more comprehensive manner by means of physiological and biomechanical methods.

OBJECTIVE: The objective of the pilot study was to compare biomechanical and physiological variables during walking without and with poles on the different slopes of the ground.

METHODS: One healthy man participated in the study. During treadmill walking, basic temporal, angle, force, energy expenditure and exercise intensity variables were observed. The subject completed two 9 minute tests (NW, normal walking) consisting of three periods of three minutes walking on various slopes of the ground $(0 \%, 5 \%, 10 \%)$.

RESULTS: NW on all slopes of the ground, in comparison with walking without poles, the result was lesser hip flexion, knee flexion and ankle dorsal flexion and greater hip extension. Maximal plantar flexion during NW was not influenced by the slope of the ground (in contrast to walking without poles).

During NW, frequency decreased on all slopes of the ground. Support impulse and maximal force utilization of the poles showed various differences for right and left limbs. The values of oxygen consumption and heart rate for NW were, in comparison with walking without poles, higher in all experimental situations.

CONCLUSIONS: The slope of the ground influences both walking without poles and NW. The reason is greater moving of the centre of mass in a vertical direction. During NW the examined person solved increased energy demands at gentle increases in the slope only by an enhancement of the work of lower limbs, whereas during the overcoming of a major inclination, to maintain the stated speed, it was necessary to enhance the involvement of the upper limbs.

Keywords: Nordic walking, kinematics, pole force, energy cost, uphill walking.

\section{INTRODUCTION}

Nordic walking (NW) has recently become a very popular physical activity and that not only in Western European countries. Its popularity has been also increasing in the Czech Republic. Many positive effects are attributed to NW, due to which it can be used for active athletes, for persons with a low fitness level, for the elderly, or for patients with various disorders.

One of the described effects of NW, among others, is an increase in stability and a decrease in the mechanical loading of the lower limb joints (Schwameder et al., 1999), which is still controversial (Hansen et al., 2008), but the rehabilitation effect is indisputable (Kocur et al., 2009; Fregly et al., 2009). Probably the most important positive effect of NW is an increase in the exercise intensity, and therefore an increase in energy expenditure (Rodgers et al., 1995; Porcari et al., 1997; Church et al., 2002; Schiffer et al., 2006). These effects are attributed to the involvement of the upper body musculature. An increase in the cardiovascular and meta- bolic load during NW is associated with "proper poling technique" (Schiffer et al., 2009), which the majority of studies did not follow. These papers are mainly focused on physiological variables, less often, and mostly apart from the analysis of kinematics of a moving subject with poles (Hansen et al., 2008; Schwameder et al., 1999; Willson et al., 2001). Until now, only one study, which observed the generation of upper limb force acting on a pole has been presented (Schiffer et al., 2009). These authors found that surface changes (concrete, lawn, and artificial track) had no effect on the force impulse generated by the poles, and the work of the upper extremities seems to be for them, in terms of propulsion, only a luxury effort.

Considering these facts, further research is necessary. NW has to be observed more comprehensively.

The aim of this pilot study was to compare biomechanical and physiological variables during walking without and with poles on flat ground and on two different slopes of the ground (5 and 10\%). 


\section{MATERIAL AND METHODS}

\section{Tested participant}

One healthy man (age 26 years) was tested. The following anthropometric and functional characteristics were observed: height $-186 \mathrm{~cm}$, weight $-86 \mathrm{~kg}$, fat mass $-7.8 \%$, skeletal muscles $-53.8 \%$, maximal oxygen consumption $\left(\mathrm{VO}_{2} \max \right)-65.4 \mathrm{ml} / \mathrm{kg} / \mathrm{min}$., maximal heart rate (HRmax) - 196 beats/min., resting heart rate (HRrest) - 43 beats/min., maximal static force generated to pole by left upper limb - $240 \mathrm{~N}$ and right upper limb $-259 \mathrm{~N}$. The subject has sufficient experience with NW technique and signed an informed consent form.

\section{Test protocol}

\section{Maximal exercise test}

At first, the tested person underwent the graded exercise test till he reached his maximum on a motor driven treadmill LODE Valiant (Netherland). Heart rate and spiroergometric variables were monitored during the test. The first 4 minutes were devoted to a warm up at walking speed of $8 \mathrm{~km} /$ hour at the grade of $0 \%$. The next step was an increase in inclination to $5 \%$ and subsequently, in one minute, the treadmill speed was increased to $10 \mathrm{~km} /$ hour. After a period of one minute, a gradual increase in speed followed every 30 seconds of about $1 \mathrm{~km} /$ hour up to $15 \mathrm{~km} /$ hour. After reaching the speed of $15 \mathrm{~km} /$ hour, the treadmill slope was increased every 30 seconds for about $2 \%$ up to the subject's volitional maximum.

\section{Walking analysis}

The test consists of: 1) 9 minutes of walking at speed $7.6 \mathrm{~km}$ per hour ( 3 minutes at a slope of $0 \%, 3$ minutes at a slope of $5 \%$ and 3 minutes at a slope of $10 \%, 2$ ) the same test with poles (two days later). During walking with poles, the subject was instructed to involve upper limbs with middle intensity.

\section{METHODS}

\section{Kinematic analysis}

For walking and NW analysis we used the $3 \mathrm{D}$ videography method (4 digital video cameras with a frequency of $50 \mathrm{~Hz}$ ). The recorded sector was $4 \times 3 \mathrm{~m}$, and the image had a resolution of $640 \times 480$ pixels, i.e. a shift of the cursor by 1 pixel was equivalent to a magnitude difference of $0.6 \mathrm{~cm}$. Video cameras were synchronized using a lighting device. Before the measurement, 19 markers were positioned on the subject: on the 5th metatarsal head (right, left), calcaneus (right, left), lateral malleolus (right, left), lateral femoral epicondyl (right, left), greater trochanter (right, left), anterior superior iliac spine (ASI) (right, left), posterior superior iliac spine (PSI) (right, left), 7th cervical vertebra (C7), 10th tho- racic vertebra (Th10), 5th lumbar vertebra (L5), and the acromion (right, left). Video recordings from cameras were processed by using the APAS system (Ariel Dynamics Inc., Trabuco Canyon, CA, USA). One gait cycle was evaluated for each condition. The following kinematic variables were evaluated: ankle plantar and dorsal flexion, knee flexion, hip flexion and extension, pelvic obliquity, pelvic rotation, shoulder obliquity, shoulder rotation, lower trunk obliquity (Th10-L5), upper trunk obliquity (C7-Th10), shoulder flexion and extension and elbow flexion. Walking frequency was determined from the recordings.

\section{Measurement of axial force and time variable}

The axial force measurements of the poles was observed using the System for Monitoring of the Pole Axial Force in Nordic Walking (MPAF) that was developed in the Department of Biomechanics and Engineering Cybernetics, Faculty of Physical Culture, Palacký University in Olomouc, the Czech Republic.

A strain-gauge transducer with the possibility of calibration (BIRKI, Czech Republic) was built into the poles as close as possible to the handgrips. The straingauge transducer was composed of a circular steel deformational element of $45 \mathrm{~mm}$ in diameter. To this element four wire strain-gauges were stuck. The straingauges were connected up to the full bridge. Differential voltage was amplified by means of a measuring amplifier. Its base was composed of the amplifying device AD623 (Analog Devices, Norwood, USA). The measuring range of the force transducer was $\pm 1000 \mathrm{~N}$. Output voltage was sampled by an A/D converter USB-1608FS (Measurement Computing, Norton, USA) and data were transported to a personal computer via USB interface. The sampling frequency was $1000 \mathrm{~Hz}$.

Calculations, storage and display of the measured values were executed using a special programme, which was done using MATLAB software (MathWorks, Natick, USA). This programme makes possible the online display of the time behaviour of the measured forces on both the right and left poles and the offline calculations of the observed variables. Mean values during the last 30 seconds of each walking period were determined. Frequency (frequency of pole impact), support impulse (force impulse during one support phase - force integral) and maximal force utilization (maximal force during one support phase expressed in percentages of maximal force exerted under static conditions) were determined. Each frequency represents the sum of values on both the left and right sides, support impulse and maximal force utilization represent the mean from the right and left sides.

\section{Measurement of energy expenditure and exercise intensity}

Indirect calorimetry, based on the monitoring of oxygen consumption, was used for the measurement of energy expenditure. Oxygen consumption, among other 
spiroergometric parameters, was monitored with the use of breath by a breath gas analyser (ZAN Ergo USB 600, Germany). To monitor the heart rate, we used the heart rate monitor Polar (Finland). During the walking test we evaluated the average values of the last 30 seconds of each 3 minute long step of the load. We considered these essential parameters: oxygen consumption - $\mathrm{VO}_{2}$ [ $\mathrm{ml} / \mathrm{kg} / \mathrm{min}$.], and heart rate - HR [beats $/ \mathrm{min}$.] of which we calculated the parameters showing exercise intensity: oxygen consumption expressed as a percentage of the maximal value of $\mathrm{VO}_{2}$ determined during the graded exercise test ( $\left.\% \mathrm{VO}_{2} \max \right)$, and heart rate expressed as a percentage of the maximal heart rate reserve - \% HRR (HRR = HRmax - HRrest).

\section{Other measurements}

Resting heart rate was measured in the morning after waking up by measuring the subject with the monitoring device Polar (Finland). The level of walking frequency (without poles) was measured by means of the Actigraph device (USA). Maximal static force exerted to the pole being used by the right or left upper limb (with the pole in a vertical direction in relation to the ground, with an elbow angle of 90 degrees) was measured three times for each limb and the maximal value was selected. The MPAF system was used for these measurements.

\section{Statistics}

Only data from the measurement of axial force were included for statistical analysis. Frequency, support impulse and maximal force utilization under various conditions were compared using the paired t-test.

\section{RESULTS}

\section{Walking without poles}

In this section the results of uphill walking are compared with level walking. The results indicate that during uphill walking without poles, maximal hip flexion and range of the hip movement were bigger and maximal hip extension smaller (TABLE 1). For both increased slopes of the ground maximal knee extension increased during the stance phase. Maximal knee flexion and range of knee movement were greater than during level walking

\section{TABLE 1}

Values of observed kinematic variables

\begin{tabular}{|c|c|c|c|c|c|c|c|}
\hline \multicolumn{2}{|l|}{ Slope [\%] } & \multicolumn{2}{|c|}{$\mathbf{0}$} & \multicolumn{2}{|c|}{5} & \multicolumn{2}{|c|}{10} \\
\hline Joint & Variable & RW & NW & RW & NW & RW & NW \\
\hline \multirow[b]{3}{*}{ Shoulder } & Max & 29.0 & -9.1 & 26.7 & 3.6 & 30.5 & 3.2 \\
\hline & Min & -26.0 & -41.7 & -26.5 & -39.7 & -31.6 & -30.2 \\
\hline & Range & 54.9 & 32.6 & 53.2 & 43.3 & 62.1 & 33.5 \\
\hline \multirow[b]{3}{*}{ Elbow } & Max & 57.6 & 86.7 & 53.1 & 75.7 & 53.3 & 68.8 \\
\hline & Min & -8.1 & 3.1 & -5.2 & 1.6 & -5.9 & 8.6 \\
\hline & Range & 65.7 & 83.6 & 58.3 & 74.1 & 59.1 & 60.1 \\
\hline \multirow[b]{3}{*}{ Hip } & Max & 32.8 & 27.7 & 36.6 & 30.8 & 43.4 & 36.6 \\
\hline & Min & -21.0 & -24.9 & -18.3 & -25.3 & -17.3 & -23.5 \\
\hline & Range & 53.8 & 52.6 & 54.8 & 56.0 & 60.6 & 60.1 \\
\hline \multirow[b]{6}{*}{ Knee } & Max1 & 34.3 & 30.0 & 31.8 & 30.3 & 37.0 & 31.2 \\
\hline & Min1 & 4.8 & 1.9 & 4.5 & -1.7 & 1.7 & -3.2 \\
\hline & Max2 & 68.8 & 55.5 & 65.2 & 53.5 & 62.7 & 54.9 \\
\hline & Min2 & 4.6 & 4.5 & 10.4 & 7.0 & 15.3 & 17.5 \\
\hline & Range Stance & 29.5 & 28.1 & 27.3 & 32.0 & 35.3 & 34.4 \\
\hline & Range Swing & 64.2 & 51.0 & 54.8 & 46.5 & 47.4 & 37.4 \\
\hline \multirow[b]{4}{*}{ Ankle } & Max1 & 0.8 & 2.3 & -6.2 & -1.8 & -15.3 & -3.7 \\
\hline & Min & -12.0 & -5.9 & -18.4 & -10.1 & -25.0 & -11.6 \\
\hline & Max2 & 22.4 & 15.8 & 13.5 & 19.7 & 3.2 & 17.8 \\
\hline & Range & 34.4 & 21.7 & 31.9 & 29.8 & 28.2 & 29.4 \\
\hline
\end{tabular}

Legend: RW - gait without poles, NW - gait with poles, Shoulder Max - maximal shoulder flexion, Shoulder Min - maximal shoulder extension, Elbow Max - maximal elbow flexion, Elbow Min - minimal elbow flexion (maximal extension), Hip Max - maximal hip flexion, Hip Min - maximal hip extension, Knee Max 1 - maximal knee flexion during loading response, Knee Min 1 - minimal knee flexion (maximal extension) during stance phase, Knee max 2 - maximal knee flexion during swing phase, Knee Min 2 - minimal knee flexion during swing phase, Ankle Max 1 - maximal plantar flexion during loading response, Ankle Min - maximal dorsal flexion, Ankle Max 2 - maximal plantar flexion during preswing a initial swing 
only on the biggest slope of the ground (10\%). During the swing phase, maximal knee flexion and range of movement were smaller. In the ankle, an increased slope of the ground results in a smaller plantar flexion and a bigger dorsal flexion; the range of the movement was smaller. With an increased slope of the ground, walking frequency was increased $(0 \%-121.1,5 \%-123.0$, $10 \%-124.7$ steps per minute). The influence of the slope of the ground on upper limb movements (shoulder and elbow) was not clear (individual variability of the experienced movement model).

The values of metabolic load ( $\left.\% \mathrm{VO}_{2} \max \right)$ and load of circulation (\% HRR) were, during walking without poles on the flat ground, around $30 \%$ and $40 \%$, respectively. An increase in the slope of the ground from $0 \%$ to $5 \%$ and from $5 \%$ to $10 \%$ caused approximately the same increase in absolute and relative values of $\mathrm{VO}_{2}$ (by about $8.5 \mathrm{ml} / \mathrm{kg} / \mathrm{min}$. and $13.5 \%$, respectively). The rise in the load of circulation (\% HRR) was smaller with an increase of slope from $0 \%$ to $5 \%$ than with an increase of slope from $5 \%$ to $10 \%$ ( $10.7 \%$ and $14.2 \%$, respectively) (TABLE 2).

\section{Comparison of Nordic Walking and walking without poles at various slopes of the ground}

During uphill walking with poles the subject had greater maximal hip flexion and range of movement in comparison with walking without poles. Maximal knee flexion, maximal knee extension and the range of movement during the stance phase were slightly bigger for NW. In the swing phase, no differences were found in maximal knee flexion, however maximal knee extension and the range of movement was smaller for NW than for walking without poles. In the ankle joint, an increased slope of the ground during NW results in a greater maximal dorsal flexion.

NW on all slopes of the ground resulted in smaller hip flexion and greater hip extension than walking with- out poles. The maximal knee flexion during each stance was smaller and maximal knee extension greater with the use of poles. During the swing phase, maximal knee flexion and the range of movement were smaller for NW. The results of ankle joints showed greater plantar and smaller dorsal flexion during NW than during walking without poles. The difference in dorsal flexion was the biggest for a slope of 10\%. Maximal plantar flexion during NW in comparison to walking without poles was not influenced by the slope of the ground.

Fig. 1

Plantar and dorsal flexion in the ankle joint during walking without and with poles at various slopes of the ground

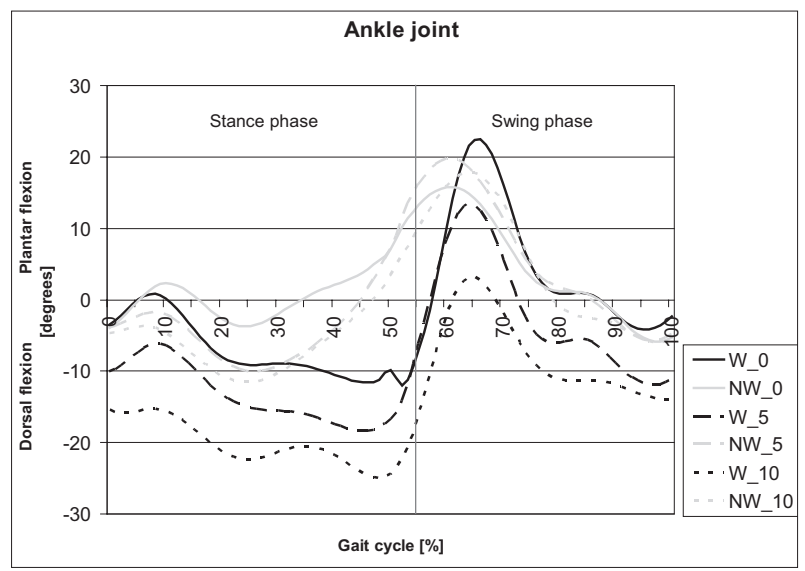

Legend: W - walking without poles, NW - Nordic walking, _0 - level walking, _5 - slope $5 \%$, _10 - slope $10 \%$

During NW, a greater slope of the ground results in a greater maximal shoulder flexion and a smaller maximal shoulder extension. Movement of the upper arm moved forward and the range of the movement was big-

\section{TABLE 2}

Energy expenditure and parameters representing exercise intensity

\begin{tabular}{|c|c|c|c|c|c|c|c|c|c|c|c|c|}
\hline \multirow[b]{2}{*}{ Slope } & \multicolumn{3}{|c|}{$\mathrm{VO}_{2}[\mathrm{ml} / \mathrm{kg} / \mathrm{min}]}$. & \multicolumn{3}{|c|}{$\% \mathrm{VO}_{2} \max$} & \multicolumn{3}{|c|}{ HR [beats/min.] } & \multicolumn{3}{|c|}{$\%$ HRR } \\
\hline & RW & NW & NW-RW & RW & NW & NW-RW & RW & NW & NW-RW & RW & NW & NW-RW \\
\hline $\mathbf{0}$ & 19.08 & 24.20 & 5.12 & 29.81 & 37.81 & 8.00 & 104.80 & 117.71 & 12.91 & 40.39 & 48.83 & 8.44 \\
\hline 5 & 27.84 & 32.11 & 4.27 & 43.50 & 50.17 & 6.67 & 121.15 & 133.90 & 12.75 & 51.08 & 59.41 & 8.33 \\
\hline 10 & 36.30 & 40.23 & 3.92 & 56.72 & 62.85 & 6.13 & 142.84 & 158.82 & 15.98 & 65.26 & 75.43 & 10.18 \\
\hline $5-0$ & 8.76 & 7.91 & & 13.69 & 12.36 & & 16.35 & 16.19 & & 10.69 & 10.58 & \\
\hline $10-5$ & 8.46 & 8.12 & & 13.22 & 12.68 & & 21.69 & 24.92 & & 14.18 & 16.02 & \\
\hline $10-0$ & 17.22 & 16.03 & & 26.91 & 25.04 & & 38.04 & 41.11 & & 24.86 & 26.60 & \\
\hline
\end{tabular}

Legend: RW - gait without poles, NW - gait with poles, NW-RW - difference between Nordic walking and regular walking, $\mathrm{VO}_{2}-\mathrm{oxygen}$ consumption, $\% \mathrm{VO}_{2}$ max - percentage of $\mathrm{VO}_{2}$ from maximal oxygen consumption, $\mathrm{HR}$ - heart rate, \% HRR - percentage of HR from maximal heart rate reserve $(\mathrm{HRR}=\mathrm{HRmax}-\mathrm{HRrest})$, Slope - elevation of hill in percentage $(0 \%, 5 \%$ and $10 \%), 5-0$ - difference between slope $5 \%$ and $0 \%, 10-5$ - difference between slope $10 \%$ and 5\%, 10-0 - difference between slope 10\% and $0 \%$ 
TABLE 3

Values of observed time and force variables

\begin{tabular}{|c|c|c|c|c|c|c|c|c|c|c|c|c|c|}
\hline \multirow{3}{*}{$\begin{array}{l}\text { Variables } \\
\text { Frequency }\end{array}$} & \multirow{3}{*}{\begin{tabular}{|c|} 
Slope [\%] \\
Units \\
{$\left[\mathrm{min}^{-1}\right]$} \\
\end{tabular}} & \multicolumn{2}{|c|}{$\mathbf{0}$} & \multicolumn{2}{|c|}{5} & \multicolumn{2}{|c|}{10} & \multirow{2}{*}{\multicolumn{2}{|c|}{0 vs 5}} & \multirow{2}{*}{\multicolumn{2}{|c|}{5 vs 10}} & \multirow{2}{*}{\multicolumn{2}{|c|}{ 0 vs 10}} \\
\hline & & Mean & SD & Mean & SD & Mean & SD & & & & & & \\
\hline & & 116.3 & 3.72 & 118.7 & 3.92 & 122.8 & 3.26 & 2.41 & $* * *$ & 4.10 & $* * *$ & 6.50 & $* * *$ \\
\hline Support impulse & [N.s] & 14.7 & 2.63 & 13.9 & 2.68 & 16.7 & 2.87 & -1.62 & $* *$ & 3.82 & $* * *$ & 2.20 & $* * *$ \\
\hline Maximal force utilization & {$[\%]$} & 25.8 & 3.34 & 24.8 & 3.39 & 31.1 & 3.95 & -2.89 & $* *$ & 7.41 & $* * *$ & 4.51 & $* * *$ \\
\hline
\end{tabular}

Legend: Frequency - frequency of pole impact, Support impulse - force impulse (force integral) during one support phase, Maximal force utilization - maximal force during one support phase expressed in percentages of maximal force exerted during static conditions, $* *-\mathrm{p}<0.01, * * *-\mathrm{p}<0.001$

ger. By comparison of NW with normal walking, maximal shoulder flexion and range of the movement were smaller, the maximal shoulder extension was bigger. Maximal elbow flexion and the range of movement were bigger and maximal elbow extension smaller for NW than walking without poles on all slopes of the ground. In cases of increased degrees of the slope, differences between walking with and without poles were smaller.

During NW, frequency decreased on all slopes of the ground. Support impulse and maximal force utilization showed various differences for right and left limbs (TABLE 3).

The increase in $\mathrm{VO}_{2}$ and \% $\mathrm{VO}_{2}$ max was approximately the same with both increases in the degree of the slope $\left(8.5 \mathrm{ml} / \mathrm{kg} / \mathrm{min}\right.$. and $12.5 \% \mathrm{VO}_{2} \max$, respectively), an increase in HR and in the \% of HRR was smaller with an increase in the degree of the slope from $0 \%$ to $5 \%$ than with an increase in the degree of the slope from $5 \%$ to $10 \%$ ( 16 vs. 25 beats/min. and 11 vs. $16 \%$ HRR, respectively) (TABLE 2).

The values of $\mathrm{VO}_{2}$ and $\mathrm{HR}$ for NW were, in comparison with walking without poles, higher in all experimental situations $(0 \%, 5 \%$ and $10 \%$ of inclination $)$. The metabolic load during walking at a $0 \%$ inclination for NW was, in comparison with walking without poles, higher by about $8 \%$; at $5 \%$ the inclination was higher by about $7 \%$, and at a $10 \%$ inclination, the metabolic load was about $6 \%$ higher. In comparison with walking without poles, the load of circulation ( $\%$ of HRR) during $\mathrm{NW}$ at the $0 \%$ and $5 \%$ inclination level was higher by about $8 \%$ and at the level of $10 \%$, the inclination was higher by about $10 \%$.

\section{DISCUSSION}

The results of this study show a greater walking frequency in connection with an increased slope of the ground. Increasing the frequency, at a constant treadmill walking speed ( $7.6 \mathrm{~km} /$ hour $)$, means a shorter step length.

During uphill walking, a subject has to make some changes to walking performance. Leroux et al. (1999) presented the information that normal subjects perform the same kinematic and motor strategy for adapting to uphill walking.

The main kinematic changes are consistent with the need to raise the swing limb (Lay et al., 2006) and the necessity of the centre of mass moving not only in a horizontal, but also in a vertical direction. Among the main adapt mechanisms are ranked increased hip flexion, increased ankle dorsal flexion and decreased knee flexion during the second half of the stance phase (Leroux et al., 1999).

The shortening of the step length has its base in a reduction of ankle plantar flexion. This reduction in ankle movement during uphill walking could be explained by a greater requirement of ankle flexor forces that are needed for greater movement in a vertical direction. It results in greater energetic demands.

The subject's values of metabolic load (ML) and load of circulation (CL) at the same speed of walking without poles during all experimental situations (except for CL on a higher slope) reflected a very low intensity of exercise. Even if we prolonged the duration of the exercise and a gradual increase in ML and a primary level in CL would happen to occur (by reason of cardiovascular drift), it is likely that walking at a speed of $7.6 \mathrm{~km} /$ hour even at the $10 \%$ inclination level wouldn't be a sufficient training factor for maintaining or enhancement in aerobic capacity for the tested subject.

Walking on a slope with a $10 \%$ inclination in comparison with walking on the flat ground, caused a nearly two-times higher increase in energy output (ML), while a relatively higher level of CL increased by about less than two-thirds. The same increase in inclination by $5 \%$ (from 0 to $5 \%$, and from 5 to $10 \%$ ) caused the same increase in energy output (ML), while the cardiovascular system responded to an increase in inclination from 5 to $10 \%$ by a higher increase in HR than during an increase from 0 to $5 \%$. This finding corresponds to the common knowledge that during very low exercise intensity the values of ML are always lower than the values of CL; which is why increasing the exercise intensity slowly equalizes the values of both parameters (Swain et al., 
1998). This difference between the dynamics of ML and $\mathrm{CL}$ with increasing exercise intensity was obviously not changed even during NW.

Compared with walking, NW exhibits a longer step length (Hansen et al., 2008). In this case the knee joint has to be in slight flexion, because a knee hyperextension would cause the overloading of the front part of the knee joint.

Some similar tendencies were found for the movement of lower limbs during NW and walking without poles (greater maximal hip flexion, walking frequency, step length, smaller maximal knee extension).

The use of walking poles enables subjects to walk at a faster speed with reduced vertical ground reaction forces, vertical knee joint reaction forces, and reduction in the knee extensor angular impulse and support moment, depending on the poling condition used (Willson et al., 2001).

Using the poles at all applied levels of the slope of the ground caused an increase in oxygen consumption. The reason for this increase in energy demands is an additional involvement of the upper body musculature. Knight and Caldewel (2000) found a decrease in the activity of some of the muscles of the lower limbs while walking with poles. That means that the involvement of upper body musculature allows for a reduction in demands made on the musculature of the lower limbs. However, the muscles of the upper limbs make relatively higher metabolic demands and produce a lower work efficiency. This finding indirectly comes from the study of Glasheen and MacMahon (1995) who described that the metabolic costs of the upper extremities is four to five times higher on the arms during running compared with running on the limbs of running quadrupeds. Hence, although there is a decrease in the energetic output of the musculature of the lower limbs, the total energetic output is increased.

The metabolic loading of our proband during NW at a higher slope reached approximately $63 \%$ of $\mathrm{VO}_{2} \max$ and the cardiovascular load reached approximately $75 \%$ of HRR. This meant that exercise intensity during NW is markedly higher in comparison with walking without poles (on applied slopes this makes up about $6-8 \%$ of the $\mathrm{VO}_{2}$ max and $8-10 \%$ of $\mathrm{HRR}$ ), nevertheless the exercise intensity was still not high enough. However, with the exercise prolongation, our proband could use NW at the speed of $7.6 \mathrm{~km} /$ hour and at a slope of $10 \%$ as a tool for the maintenance of his aerobic capacity (Gormley et al., 2008). Involvement of the upper limbs during NW on particular slopes of the ground varied. The data showed that axial force generated to the pole decreased during uphill walking with a $5 \%$ slope. A considerable increase was found only in uphill walking with a slope of $10 \%$. This implies that an increase in energy expenditure during walking up a slight slope was not caused by the upper limb muscles (the smallest difference between shoulder movement while walking with and without poles), but almost exclusively by the lower limb muscles. In this case an increase of forces during the heel off is associated with an increase in the range of the knee movement during the stance phase, plantar flexion at the beginning of the swing phase and the range of the ankles' movement.

During walking up a greater slope on the ground (10\%) no increase of plantar and dorsal flexion was shown. Thus maintenance of walking speed demands the involvement of the upper limb muscles. A similar conclusion was also presented by Jacobson et al. (2000). They demonstrated that an increased slope of the ground increases the efficiency of forces that are generated by the upper limbs. It is possible that greater energetic requirements were spontaneously covered by an increase in lower limb force. A further increase in the energetic cost of uphill walking (slope $10 \%$ ) requires involvement of the upper limbs.

From the propulsion point of view (forward movement), Shiffer et al. (2008) consider walking with poles as a „luxury effort“. Lower limbs work is the most dominant. However, the above mentioned results of our study showed that, at $10 \%$ inclination, the proband has to spontaneously increase the involvement of the upper limb muscles to maintain walking speed. Under these conditions, the "luxury effort" of walking with poles is reduced.

For future research there are many possibilities. NW could be observed more comprehensively. There are also many various possibilities of data processing, which can bring new findings to light. For example, the application of angle-angle diagrams in kinematics can be useful for predicting the motion of lower extremities (Kutilek \& Farkasova, 2011) or for better understanding of relationships between segments under different conditions.

The main limits of the study correspond to the fact that only one person was measured. The obtained data can be influenced by the measurement conditions or the individual movement stereotype of the observed subject. The main advantage of our pilot study was that NW was observed more comprehensively by means of several physiological and biomechanical methods.

\section{CONCLUSION}

The slope of the ground influences both walking without poles and NW. This influence is associated with the moving centre of mass more in a vertical direction, which is demonstrated by a greater raising of the swing limb. It results in a greater energy cost and circulation load. 
$\mathrm{NW}$ at a $5 \%$ level of inclination was energetically more demanding than NW on the flat ground, despite of no increase in the forces generated by the upper limbs. On the contrary, the forces even decreased. Obviously, the increased energetic demands resulted from the increase in the work of the lower limbs. The increased inclination of $10 \%$ caused an increase in both energy demands and the power generated by the upper limbs. From that we could deduce that the examined person solved increased energy demands as a response to the gentle increase in the slope only by enhancement of the work of the lower limbs, whereas during the negotiation of a major inclination, to maintain the stated speed, it was necessary to enhance the involvement of the upper limbs.

Our data can not be generalized to the whole population. Future research with the observation of a large sample is necessary.

\section{ACKNOWLEDGMENT}

The study has been supported by the research grant from the Ministry of Education, Youth and Sports of the Czech Republic (No. MSM 6198959221) "Physical Activity and Inactivity of the Inhabitants of the Czech Republic in the Context of Behavioral Changes".

\section{REFERENCES}

Fregly, B. J., D’Lima, D. D., \& Colwell, C. W. Jr. (2009). Effective gait patterns for offloading the medial compartment of the knee. J. Orthop. Res., 27(8), 1016-1021.

Glasheen, J. W., \& McMahon, T. A. (1995). Arms are different from legs: mechanics and energetics of human hand running. J. Appl. Physiol., 78(4), 1280-1287.

Gormley, S. E., Swain, D. P., High, R., Spina, R. J., Dowling, E. A., Kotipalli, U. S., \& Gandrakota, R. (2008). Effect of intensity of aerobic training on $\mathrm{VO}_{2}$ max. Med. Sci. Sports Exerc., 40(7), 1336-1343.

Hansen, L., Henriksen, M., Larsen, P., \& Alkjaer, T. (2008). Nordic Walking does not reduce the loading of the knee joint. Scand. J. Med. Sci. Sports, 18, 436-441.

Church, T. S., Ernest, C. P., \& Morss, G. M. (2002). Field testing of physiological responses associated with Nordic Walking. Res. Q. Exerc. Sport, 73(3), 296-300.

Jacobson, B. H., Wright, T., \& Dugan, B. (2000). Load carriage energy expenditure with and without hiking poles during inclined walking. Int. J. Sports Med., 21, 356-359.

Knight, C. A., \& Caldwell, G. E. (2000). Muscular and metabolic costs of uphill backpacking: Are hiking poles beneficial? Med. Sci. Sports Exerc., 32(12), 2093-2101.

Kocur, P., Deskur-Smielecka, E., Wilk, M., \& Dylewicz, P. (2009). Effects of Nordic Walking training on exercise capacity and fitness in men participating in early, short term inpatient cardiac rehabilitation after an acute coronary syndrome - a controlled trial. Int. J. Rehabil., 32(2), 132-138.

Kutilek, P., \& Farkasova, B. (2011). Prediction of lower extremities' movement by angle-angle diagrams and neural network. Acta Bioeng. Biomech., 13(2), 57-65.

Lay, A. N., Hass, C. J., \& Gregor, R. J. (2006).The effects of sloped surfaces on locomotion: A kinematic and kinetic analysis. J. Biomech., 39, 1621-1628.

Leroux, A., Fung, J., \& Barbeau, H. (1999). Adaptation of the walking pattern to uphill walking in normal and spinal cord injured subjects. Exp. Brain Res., 126, 359-368.

Porcari, J. P., Hendrickson, T. L., Walter, P. R., Terry, L., \& Walsko, G. (1997). The physiological responses to walking with and without Power Poles on treadmill exercise. Res. Q. Exerc. Sport, 68(2), 161-166.

Rodgers, C. D, VanHeest, J. L., \& Schachter, C. L. (1995). Energy expenditure during submaximal walking with Exerstriders. Med. Sci. Sports Exerc., 27(4), 607-611.

Schiffer, T., Knicker, A., Dannöhl, R., \& Strüder, K. (2009). Energy cost and pole forces during Nordic Walking under different surface conditions. Med. Sci. Sports Exerc., 41(3), 663-668.

Schiffer, T., Knicker, A., Hoffman, U., Harwig, B., Hollmann, W., \& Strüder, H. K. (2006). Physiological responses to Nordic walking, walking and jogging. Eur. J. Appl. Physiol., 98(1), 56-61.

Schwameder, H., Roithner, R., Muller, E., Niessen, W., \& Raschner, C. (1999). Knee joint forces during downhill walking with hiking poles. J. Sport Sci., 17, 969-978.

Swain, D. P., Leutholtz, B. C., King, M. E., Haas, L. A., \& Branch, J. D. (1998). Relationship between \% heart rate reserve and \% $\mathrm{VO}_{2}$ in treadmill exercise. Med. Sci. Sports Exerc., 30(2), 318-321.

Willson, J., Torry, M. R., Decker, M. J., Kernozek, T., \& Steadman, J. R. (2001). Effects of walking poles on lower extremity gait mechanics. Med. Sci. Sports Exerc., 33(1), 142-147.

\section{KINEMATICKÁ ANALÝZA, SÍLA HOLÍ A SPOTŘEBA ENERGIE U SEVERSKÉ CHŮZE - VLIV SKLONU PODLOŽKY}

(Souhrn anglického textu)

VÝCHODISKA: Několik studií, které se týkají severské chůze, bylo již publikováno, avšak obvykle byly zaměřeny na fyziologické nebo kinematické parametry. Až 
do současnosti byla prezentována pouze jedna studie, která zkoumala velikost síly, kterou při severské chůzi působí subjekt na hole. V naší pilotní studii je severská chůze posuzována komplexněji prostřednictvím fyziologických a biomechanických metod.

CÍlE: Cílem pilotní studie bylo porovnat biomechanické a fyziologické parametry při chůzi s a bez holí při různém sklonu podložky.

METODIKA: Studie se zúčastnil jeden muž. Při chůzi na běhátku byly sledovány základní časové, úhlové a silové parametry, spotřeba energie a intenzita zatižení. Subjekt absolvoval devítiminutové měření (severská chůze, chůze), které se skládalo ze tř́i tříminutových intervalů s různým sklonem podložky $(0 \%, 5 \%, 10 \%)$.

VÝSLEDKY: Severská chůze se vzhledem k chůzi bez holí vyznačovala při všech sklonech podložky menší flexí v kyčelním a kolenním kloubu, menší dorzální flexí v hlezenním kloubu a větší extenzí v kyčelním kloubu. Maximum plantární flexe při severské chůzi nebylo ovlivněno sklonem povrchu (na rozdíl od chůze bez holí). Při severské chůzi došlo ve všech sklonech podložky ke snížení frekvence kroku. Parametry velikost impulsu síly a maximální využití síly odvozené ze síly naměřené na holích vykazoval rozdíly mezi pravou a levou končetinou. Spotřeba kyslíku a srdeční frekvence při severské chůzi byly při srovnání s chůzí bez holí větší ve všech sledovaných podmínkách.

ZÁVĚRY: Sklon podložky ovlivňuje jak chůzi bez holí, tak chůzi s holemi. Důvodem je větší pohyb těžiště ve vertikálním směru. Při severské chůzi a mírném sklonu podložky vyšetřovaná osoba reagovala na vyšší energetické požadavky pouze zvýšením práce dolních končetin, zatímco při větším sklonu bylo nezbytné zapojení horních končetin.

Klícová slova: severská chioze, kinematika, síla holí, spotřeba energie, chůze do kopce.

\section{Mgr. Zdeněk Svoboda, Ph.D.}

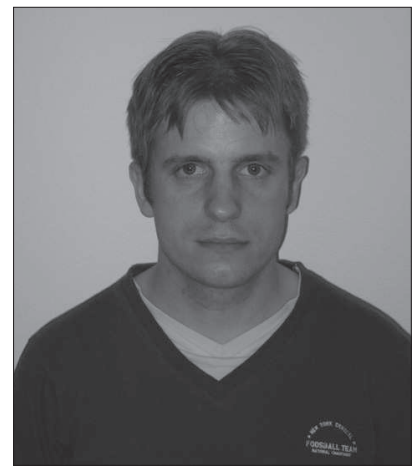

Palacký University

Faculty of Physical Culture tř. Míru 115

77111 Olomouc

Czech Republic

Education and previous work experience

2003-2007 - Ph.D. study program at the Faculty of Physical Culture, Palacký University, Olomouc.

\section{First-line publications}

Janura, M., \& Svoboda, Z. (2008). Dynamic pressure measurements in below knee prosthetics. In K. D'Août, K. Lescrenier, B. Van Gheluwe, \& D. De Clercq (Eds.), Advances in plantar pressure measurements in clinical and scientific research (pp. 171-190). Maastricht: Shaker Publishing BV.

Janura, M., Dvořáková, T., Peham, C., Svoboda, Z., \& Elfmark, M. (2010). The influence of walking speed on equine back motion in relation to hippotherapy. Wien Tierärztl Mschr, 97(3+4), 87-91.

Svoboda, Z., Janura, M., Cabell, L., \& Elfmark, M. (2011). Kinematic analysis of the flight phase of the Nordic combined and ski jump on a large hill (HS-134 m) during the 2009 Nordic World Ski Championships. Acta of Bioeng. Biomech., 13(1), 19-25.

Svoboda, Z., \& Janura, M. (2007). Temporal symmetry of sound and prosthetic limbs during transtibial amputee gait with various prosthetic alignment. Acta Universitatis Palackianae Olomucensis. Gymnica, 37(4), 55-60.

Vařeková, R., Vařeka, I., Janura, M., Svoboda, Z., \& Elfmark, M. (2011). Evaluation of postural asymmetry and gross joint mobility in elite female volleyball athletes. J. Human Kinet., 27(1), 5-13. 